\title{
Shaker-related Potassium Channel, Kv1.4, mRNA Regulation in Cultured Rat Heart Myocytes and Differential Expression of Kv1.4 and Kv1.5 Genes in Myocardial Development and Hypertrophy
}

\author{
Hiroaki Matsubara, Junichi Suzuki, and Mitsuo Inada \\ Second Department of Internal Medicine, Kansai Medical University, Moriguchi, Osaka 570, Japan
}

\begin{abstract}
The multiple $\mathrm{K}^{+}$channels are crucial for repolarization and configuration of the action potential in the neuronal and cardiac cells. In this study, we report the regulatory mechanisms of rapidly inactivating Shaker Kv1.4 channel transcript in the rat heart. Quantitative PCR analysis showed that stimulation with high concentration of $\mathrm{KCl}, \mathrm{BAY}-\mathrm{K}$ 8644, or 12- $O$-tetradecanoyl phorbol-13-acetate resulted in an immediate and substantial increase ( two- to threefold) of Kv1.4 mRNA levels in spontaneously beating myocytes prepared from neonatal rat ventricles. The Kv1.4 mRNA in the ventricle remains at a steady state level after birth and gradually declines with maturation. These results suggest that the Kv1.4 mRNA level is not static and undergoes dynamic modulation by multiple factors that activate intracellular signals. In addition, the expression patterns of $\mathrm{Kv1.4}$ as well as the delayed rectifier Shaker $\mathrm{K}^{+}$channel Kv1.5 mRNAs were examined in hypertrophied ventricles in which a plateau phase of action potential is remarkably prolonged. The Kv1.5 mRNA level was dramatically repressed while the Kv1.4 mRNA level was remarkably increased. This differential regulation was completely reversed by the normalization of hypertrophy, suggesting that the pathological alterations of $\mathrm{K}^{+}$channel gene regulation may be involved in the occurrence of ventricular arrhythmias in hypertrophic hearts. (J. Clin. Invest. 1993. 92:1659-1666.) Key words: potassium channel genes $\bullet$ delayed rectifier $\bullet$ transient outward current • myocardial hypertrophy • spontaneously hypertensive rat
\end{abstract}

\section{Introduction}

The multiple $\mathrm{K}^{+}$channels are important for repolarization and configuration of action potential in neuronal and cardiac cells (1). Despite detailed biophysiological and pharmacological characterization of heterologously expressed channels, the exact physiological function and transcriptional regulation of specific $\mathrm{K}^{+}$channel gene product in the mammalian heart have not been elucidated. In the rat heart, four distinct Shaker (Kv1.1, Kv1.2, Kv1.4, and Kv1.5), 1 Shal (Kv4.2), and 1 Shab $\mathrm{K}^{+}$channels (Kv2.1) are reported to be expressed (2).

Address correspondence to Dr. Hiroaki Matsubara, Second Department of Internal Medicine, Kansai Medical University, Fumizonocho 1, Moriguchi, Osaka 570, Japan.

Received for publication 27 October 1992 and in revised form 4 May 1993.

J. Clin. Invest.

(C) The American Society for Clinical Investigation, Inc. $0021-9738 / 93 / 10 / 1659 / 08 \quad \$ 2.00$

Volume 92, October 1993, 1659-1666
They show extensive amino acid sequence identity with Shaker $\mathrm{K}^{+}$channels over the putative membrane-spanning core region and most of these mammalian homologs, when expressed individually in Xenopus oocytes, produce noninactivating or very slowly inactivating currents. The exception in this subfamily is Kv1.4, which elicits a rapidly inactivating A-type current in Xenopus oocytes (3).

We have previously reported Northern blot hybridization and RNase protection analyses indicating that the transcript encoding for Kv1.5 is expressed in heart, skeletal muscle, and brain. The transcript is regulated in a tissue and developmentally specific manner (4). In addition, we reported the isolation of a genomic clone where a cAMP responsive element was identified in the 5' noncoding region of the channel. Our results document that an elevation in intracellular cAMP increases the steady state levels of Kv1.5 transcript in spontaneously beating neonatal rat atrial cells, suggesting that the expressional patterns of $\mathrm{K}^{+}$channel genes are not static (5). If a physiological $\mathrm{K}^{+}$channel unit in the membrane is assembled with heterogenous $\mathrm{K}^{+}$channel gene products, changes in delayed rectifier Kv1.5 gene expression may affect formation of $\mathrm{K}^{+}$channel protein. In the first part of this study we focused on regulatory mechanisms for the gene expression of a rapidly inactivating A-type Kv1.4 channel, another important $\mathrm{K}^{+}$channel in the Shaker subfamily, distinct in terms of expressed currents. Interestingly, its developmental pattern in the heart is quite distinct from that of delayed rectifier $\mathrm{Kv1.5}$. It is possible that the $\mathrm{Kv1} .4$ transcript is regulated by intracellular calcium mobilization and protein kinase $\mathrm{C}(\mathrm{PKC}){ }^{1}$

Cardiac hypertrophy is associated with changes in a wide range of intracellular signals, such as increased intracellular calcium, cAMP, inositol phosphates, and diacylglycerol concentrations (for review see reference 6). Because the gene expressions of Kv1.4 and Kv1.5 channels could be modulated by these signals, and also because the plateau phase of action potential in hypertrophic myocardium is reported to be greatly prolonged (7-9), we reasoned that cardiac hypertrophy would regulate the expressional patterns of these genes in the heart. In the second part of this study we demonstrate that the steady state levels of Kv1.4 and Kvl.5 gene expression are differentially regulated in response to cardiac hypertrophy. The hypertrophy-dependent differential regulation of Kv1.4 and Kv1.5 mRNAs in the heart raises the possibility that the formation of voltage-gated $\mathrm{K}^{+}$channel protein on the membrane can be changed in either physiological or pathophysiological states.

1. Abbreviations used in this paper: $\mathrm{ACE}$, angiotensin I converting enzyme; ANF, atrial natriuretic factor; PKC, protein kinease C; RHR, renovascular hypertensive rat; $R T$, reverse transcription; SHR, spontaneously hypertensive rat; $2 \mathrm{~K} 1 \mathrm{C}$, two-kidney, one clip; TPA, 12-O-tetradecanoyl phorbol-13-acetate; WKY, Wistar Kyoto rat. 


\section{Methods}

Primary cultures. Primary culture of neonatal rat ventricular myocytes was prepared as described previously (10). In brief, ventricles removed from neonatal Kbl: Wistar rats (1-3 d after birth) were dissociated by stirring gently with $0.25 \%$ trypsin solution for $5 \mathrm{~min}$. After discarding the first extraction to remove red blood cells, the remaining tissues were further digested by stirring with the fresh enzyme. After $10 \mathrm{~min}$, the cells in the supernatant were removed and placed into ice-cold DME with $20 \%$ FBS. This extraction procedure was repeated $7-10$ times. The combined cell suspensions were passed through $100-\mu \mathrm{m}$ nylon mesh and centrifuged. The cell pellets, which consisted primarily of cardiomyocytes and nonmuscle cells, were resuspended in $20 \mathrm{ml}$ of DME with $10 \%$ FBS. The cell suspensions were incubated for $90 \mathrm{~min}$ at $37^{\circ} \mathrm{C}$ in 100-mm dishes, which allowed for selective attachment of nonmuscle cells to the dishes as described elsewhere (11). The cardiomyocyteenriched suspensions were removed from the culture dishes and replaced with DME containing $10 \%$ FBS and $100 \mu \mathrm{M}$ of the DNA synthesis inhibitor, bromodeoxyuridine. The cardiomyocytes were seeded at densities of $3 \times 10^{6}$ cells per 100 -mm dish. Each dispersion procedure yielded an average of 20 dishes from 40 neonatal rat ventricles, which were divided for the experiments. Each culture experiment was repeated with four separate samples obtained from four different preparations. The cells were incubated at $37^{\circ} \mathrm{C}$ under a humidified atmosphere of $95 \%$ air $-5 \% \mathrm{CO}_{2}$. After $48 \mathrm{~h}$, the cells were rinsed with PBS, and the medium was replaced with serum-free DME containing $5.4 \mathrm{mM} \mathrm{KCl}$, into which various chemicals were added to observe effects on $\mathrm{K}^{+}$ channel mRNA levels. In this experimental condition, the cultured cells were spontaneously beating, which was consistent with the observations in other studies $(12,13)$.

To obtain nonmuscle cell-enriched fraction, the culture dishes containing attached nonmuscle cells were plated into an incubator and passaged $48 \mathrm{~h}$ later with $0.25 \%$ trypsin, as described elsewhere (11). The cells were plated in DME containing $10 \%$ FBS at a density of 2 $\times 10^{4}$ cells in a $100-\mathrm{mm}$ culture dish. After $5 \mathrm{~d}$, the media were aspirated, and cells were washed with PBS and treated with guanidium isothiocyanate cesium chloride to obtain cellular RNA.

Quantitative reverse transcription (RT) and PCR assay. First strand cDNA was synthesized from total RNA isolated by guanidium isothiocyanate-cesium chloride centrifugation (14) with the Gene Amp RNA PCR kit from Perkin-Elmer Cetus Corp. (Norwalk, CT) with random hexamers as primers. In brief, total RNA samples were transcribed with random hexamers $(2.5 \mu \mathrm{M})$, dNTPs $(1 \mathrm{mM})$ and RNase inhibitors $(1 \mathrm{U} / \mu \mathrm{l})$ using MMLV reverse transcriptase $(2.5$ $\mathrm{U} / \mu \mathrm{l}$ ) for $15 \mathrm{~min}$ at $42^{\circ} \mathrm{C}$, as indicated in the kit protocol. The resultant single strand cDNA was assayed for levels of specific cDNA by quantitative PCR. The following PCR oligonucleotide primers were chosen to amplify the cDNA. The sense and antisense primers for Kv1.4 were designed from coding region of RCK4 (3): sense (5'-GCTCACTCCAGGGCAGCTGCAGCTGCTGCT, nucleotides 100-131 of RCK4) and antisense ( 5'-TCACGCATGCTGGCTCTTAGGGTGTGGCCC, nucleotides 1408-1439 of RCK4). The sense and antisense primers for Kv1.5 were designed from coding region and 3' noncoding region of Kvl (15): sense (5'-GCCTGGAGACTCTGCCTGAGTTCAGGGATG, nucleotides 776-806 of Kv1) and antisense (5'-GGTGTAAAGCAGATGCCCAGGCTCAAGGGG, nucleotides 18571888 of $\mathrm{Kvl}$ ). The sense and antisense primers for $\beta$-actin were designed from coding region (16): sense ( 5 '-GTTCCGATGCCCCGAGGATCT) and antisense (5'-GCATTTGCGGTGCACGATGGA). To obtain deletion mutated RNA $(\Delta \mathrm{Kv} 1.4)$, the 1,340 bp of $\mathrm{Kv} 1.4$ RT-PCR product prepared from total RNA of neonatal (1-d) rat ventricles was blunt-ended to attach HindIII phosphorylated linker (New England Biolabs Inc., Beverly, MA) and subcloned into HindIII site of pBluescript II KS(-) (Stratagene Inc., La Jolla, CA), which was designated as pKS. The pKS was cut by StyI and self-ligated. To get $\Delta \mathrm{Kv} 1.5$, the 2,522-bp ApaI-HindIII fragment of Kv1.5 cDNA that we cloned previously (4) was subcloned into pBluescript II KS(-), cut with Msc I and self-ligated. These plasmids contained the insert, which lacked
StyI-Styl ( $947 \mathrm{bp}$ ) of Kv1.4 RT-PCR product and Msc I-Msc I ( 782 bp) of Kv1.5 cDNA. The deletion-mutated RNAs ( $\Delta \mathrm{Kv1.4}$ and $\Delta \mathrm{Kv1}$.5) were synthesized by $\mathrm{T}_{3}$ RNA polymerase (Takara Shuzo, Kyoto, Japan ) after being linearized with EcoRI and HindIII, respectively, as described elsewhere (17). Total RNA ( $500 \mathrm{ng}$ for cells and 1 $\mu \mathrm{g}$ for tissues) and the deletion-mutated RNA (10 pg) were simultaneously mixed and transcribed with reverse transcriptase followed by amplification with PCR using primers for Kv1.4 or Kv1.5. Denaturing, annealing, and polymerase reactions for cellular RNA were done 25 times at $94^{\circ} \mathrm{C}$ for $45 \mathrm{~s}, 62^{\circ} \mathrm{C}$ for $1 \mathrm{~min}$, and $72^{\circ} \mathrm{C}$ for $1.5 \mathrm{~min}$, respectively. The PCR program for tissue RNA was 30 times at $94^{\circ} \mathrm{C}$ for $45 \mathrm{~s}$, $60^{\circ} \mathrm{C}$ for $1 \mathrm{~min}$, and $72^{\circ} \mathrm{C}$ for $1 \mathrm{~min}$, respectively. The sizes of RTPCR products for Kv1.4 mRNA and $\Delta \mathrm{Kv1.4}$ RNA, Kv1.5 mRNA, and $\Delta \mathrm{Kv1} .5$ RNA were 1340 and $393 \mathrm{bp}, 1,110$ and $328 \mathrm{bp}$, respectively. In each experiment, the same total RNA samples $(100 \mathrm{ng})$ were separately transcribed and amplified with PCR using $\beta$-actin primers. The PCR schedule of cellular and tissue RNA for $\beta$-actin was 25 cycles of $94^{\circ} \mathrm{C}$ for $30 \mathrm{~s}, 50^{\circ} \mathrm{C}$ for $30 \mathrm{~s}$, and $72^{\circ} \mathrm{C}$ for $45 \mathrm{~s}$, which gave $361 \mathrm{bp}$ of $\beta$-actin fragments. All RT-PCR products were electrophoresed on $1 \%$ agarose gels. Specificity of gene amplification was confirmed by correspondence of the size of PCR products to that predicted from the CDNA sequence and by restriction digestion pattern, and sequencing of PCR product using sense and antisense oligos as primers.

To quantify the Kv1.4 and Kv1.5 mRNAs, the trace amount ( 5 $\mu \mathrm{Ci})$ of $\left[{ }^{32} \mathrm{P}\right] \mathrm{dCTP}$ was included in the PCR reaction mixture. The bands of interest were excised from the agarose gel and analyzed in a scintillation counter to measure ${ }^{32} \mathrm{P}$ incorporation and thus the quantity of PCR product. To control for the variability in the amount of input RNA and the efficiency of PCR amplification against tube-totube variation, $\mathrm{K}^{+}$channel signals were normalized to both $\beta$-actin signals (as internal control) and deletion-mutated RNA signals (for PCR efficiency); the ${ }^{32} \mathrm{P}$ amounts incorporated in $\mathrm{K}^{+}$channel signals were normalized with those in RT-PCR bands of $\beta$-actin and respective deletion mutations. In the experiments to examine the different time points following the addition of stimulants, the value at " 0 " time point was normalized to " 1 " arbitrary unit for quantitative comparison: $\mathrm{Kv}$ signal $(\mathrm{cpm}) /[\Delta \mathrm{Kv}$ signal $(\mathrm{cpm}) \times \beta$-actin signal $(\mathrm{cpm})]$ was arbitrarily normalized to " 1 " unit.

Analysis of ventricular atrial natriuretic factor $(A N F) m R N A$. For quantitative analyses of ANF mRNA, RNA samples that had been diluted serially five times were dotted on nitrocellulose filters; 0.625 $10-\mu \mathrm{g}$ total ventricular RNA samples were applied to the filters. The filters were air-dried, baked at $80^{\circ} \mathrm{C}$ for $2 \mathrm{~h}$, and prehybridized and hybridized to the radiolabeled rat ANF complementary DNA probe (782 bp), as described previously (14). The autoradiographic signals were measured by a scanning densitometer and plotted as a function of amounts of dotted RNA. Dot blot hybridization was performed for separate RNA samples ( $n=5$ for spontaneously hypertensive rats [SHR]; $n=4$ for Wistar Kyoto rats [WKY]) obtained from each experimental group. The mean of the slopes in the linear regression of these plots was taken as a quantitative index of relative ANF mRNA.

Animals. Male SHR at ages of 17,20 , and $24 \mathrm{wk}(n=5$, respectively) and age-matched male ( $n=4$, respectively), genetically normotensive control strains, were used in the study. Two-kidney, one-clip renovascular hypertensive rats ( $2 \mathrm{~K} 1 \mathrm{C}$ RHR) were produced in male $\mathrm{Kbl}$ : Wistar rats (4-wk-old) by placing a silver clip $(0.2 \mathrm{~mm})$ on the left renal artery and leaving the contralateral kidney untouched (14). Sham-operated rats served as controls. In the experiment to examine developmental changes of $\mathrm{K}^{+}$channels mRNA levels, male Crj: Sprague-Dawley rats were used. Animals were housed in a temperature-, humidity-, and light-controlled room, and a standard rat diet and water were provided ad lib. Systolic blood pressure and heart rate were measured once a week using the tail-cuff method, and body weight was checked. When systolic blood pressure reached a level greater than 160 $\mathrm{mmHg}$ within $2 \mathrm{wk}$ after clipping, the rats were regarded as renovascular hypertensive rats. On the day of experiment, the rats were killed by decapitation. The heart was removed and the half of apex in the left ventricle was used for RNA preparation. 
A

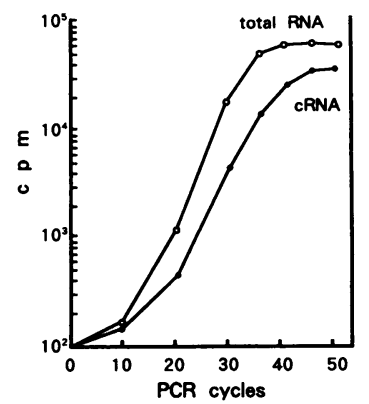

B

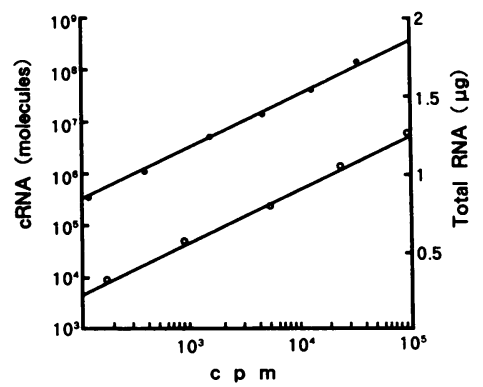

Figure 1. RT-PCR quantification of Kv1.4 mRNA in neonatal rat ventricular myocytes. $(A)$ Total RNA from neonatal rat ventricular myocytes $(1 \mu \mathrm{g}, O)$ and $1 \times 10^{7} \mathrm{cRNA}$ molecules of internal PCR standard $(\Delta \mathrm{Kv1} .4, \bullet)$ were co-amplified for various numbers of PCR cycles. $(B)$ Serial dilutions of neonatal rat ventricular myocytes total RNA $(O)$ and cRNA of internal PCR standard $(\bullet)$ were coamplified for 30 cycles. Five $\mu \mathrm{Ci}$ of $\left[{ }^{32} \mathrm{P}\right] \mathrm{dCTP}$ was included in each PCR reaction mixture. Samples were loaded on an agarose gel, and bands were excised to measure their radioactivities.

Reversal of renovascular hypertension. 6 wk after clipping, RHR were divided into three groups. We reduced the high blood pressure by two procedures. The first group $(n=4)$ was treated with the converting enzyme inhibitor enalapril (Banyu Pharmaceutical, Tokyo, Japan). The drug was given in distilled water by oral gavage ( $2 \mathrm{mg} / \mathrm{kg}$ body wt) twice daily for $4 \mathrm{wk}$. In the second group $(n=4)$, the clipped kidney was removed under ether anesthesia. The remaining group of RHR received neither drug treatment nor nephrectomy, and henceforth, this group is referred to as untreated RHR. They were examined at $6 \mathrm{wk}$ ( $n$ $=4)$ and $10 \mathrm{wk}(n=4)$ after clipping. In addition, the sham-operated control rats were also examined $6 \mathrm{wk}(n=4)$ and $10 \mathrm{wk}(n=4)$ after sham-operation.

Reagents and statistical methods. All reagents were purchased from Sigma Chemical Co. (St. Louis, MO), unless otherwise indicated below. $\mathrm{KCl}, \mathrm{H}-7$, and dibutyryl cAMP were dissolved in distilled water. BAY-K 8644, nifedipine (a gift from Bayer Co. Ltd., Tokyo, Japan) and 12-O-tetradecanoyl phorbol-13-acetate (TPA) were dissolved in DMSO. The final DMSO concentration of at most $0.05 \%$ did not affect $\mathrm{Kv}$ channel mRNA levels. Results are expressed as mean \pm SEM. Analyses of variance and the Neumann-Keuls test were used for multigroup comparisons. Values of $P<0.05$ were considered statistically significant.

\section{Results}

$R T-P C R$ quantification. We have utilized a method for quantification of mRNA levels based on randomly primed RTPCR, as described by Wang et al. (18) because of the low level of Kv1.4 gene expression in the heart. To optimize the quantitative RT-PCR, the range of concentrations of sample RNA and cRNA as well as the number of amplification cycles were chosen within the exponential phase (Fig. $1 A$ ), where the quantity of the amplified product would be directly proportional to the quantity of the starting target sequence. A linear relationship in the ratio of sample RNA to cRNA was maintained throughout the range we observed (Fig. $1 B$ ).

Effect of high concentration $\mathrm{KCl}$ on the $\mathrm{Kv1.4} \mathrm{mRNA}$ levels in spontaneously beating neonatal rat ventricular myocytes. The delayed rectifier Kv1.5 mRNA levels increased significantly with the addition of high concentration $(50 \mathrm{mM}) \mathrm{KCl}$ in the spontaneously beating atrial myocytes (19). Fig. $2 A$ shows the effect of the high concentration $\mathrm{KCl}$ on the $\mathrm{Kv1.4}$ mRNA levels in spontaneously beating ventricular myocytes. These cells were employed in the experiment to examine the Kv1.4 mRNA levels, because the Kv1.4 expression levels in cultured neonatal ventricular cells appeared to be more abundant than those in atrial cells. RT-PCR analyses demonstrate that the addition of high concentration $(50 \mathrm{mM}) \mathrm{KCl}$ causes a two- to threefold increase in the Kv1.4 mRNA levels detected as early as $1 \mathrm{~h}$ after the addition (Fig. $2 A$ ). This level of stimulation was maintained for at least $6 \mathrm{~h}$. Over the time course of this experiment, RT-PCR products of $\beta$-actin, used as an internal control for RNA input, were consistently unchanged (Fig. 2 $A$ ). Based on scintillation counting of the PCR product bands, the products of Kv1.4 were arbitrarily normalized with $\beta$-actin and deletion mutated RNA of Kv1.4, and the statistical data were shown.

Although the above experiments were carried out using cardiomyocyte-enriched culture cells obtained by the differential plating procedure described in Methods, it seemed impossible to remove nonmuscle cells completely from the culture fraction. Therefore, we examined the Kv1.4 mRNA levels in nonmuscle cell-enriched fractions obtained by the differential plating at the same time as cardiomyocyte-enriched cells, in order to see whether or not the nonmuscle cells would have any
A
B

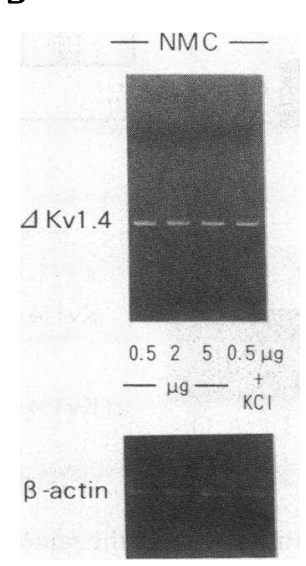

Figure 2. RT-PCR analyses of Kv1.4 mRNA levels derived from $\mathrm{KCl}$ depolarized ventricular myocytes. $(A)$ Neonatal Wistar rat ventricular myocytes were treated with $50 \mathrm{mM} \mathrm{KCl}$ in the serum-free media for the indicated time (in hours). Cellular RNA and deletion mutated Kv1.4 RNA ( $\Delta \mathrm{Kv} 1.4)$ were assayed in RT-PCR. Amplified cDNA of $\mathrm{Kv} 1.4$ treated in the presence ( $\square$ ) or absence ( $\square$ ) of additional $\mathrm{KCl}$ was normalized with the PCR products of $\Delta \mathrm{Kv} 1.4$ and $\beta$-actin, as described in Methods. Experiments were repeated four times and the mean \pm SEM values $(n=4)$ are

shown. ${ }^{*} P<0.01$ vs. values in the absence of additional $\mathrm{KCl}$. $(B)$ Cellular RNA ( $500 \mathrm{ng}, 2 \mu \mathrm{g}$, or $5 \mu \mathrm{g}$ ) prepared from nonmuscle cell-enriched culture cells $(N M C)$ and $\triangle \mathrm{Kv1.4} \mathrm{cRNA}(10 \mathrm{pg})$ were analyzed with RT-PCR. $\mathrm{KCl}(50 \mathrm{mM})$ was added into NMC culture and incubated for $2 \mathrm{~h}$. 
effect on the Kv1.4 transcript. As shown in Fig. $2 B, 500 \mathrm{ng}$ (the same amount used in cardiomyocyte-enriched culture), $2 \mu \mathrm{g}$, or $5 \mu \mathrm{g}$ of total RNA prepared from the nonmuscle cellenriched fraction did not produce any Kv1.4 mRNA signals in our RT-PCR analyses. In addition, high concentration (50 $\mathrm{mM}) \mathrm{KCl}$ did not have any effect on Kv1.4 mRNA levels, suggesting that the contamination of nonmuscle cells in the cardiomyocyte-enriched fraction is negligible in evaluating the mRNA regulation.

Effects of BAY-K 8644 and TPA on the Kv1.4 mRNA levels in spontaneously beating neonatal rat ventricular myocytes. The high concentration of $\mathrm{KCl}$ induces an increase in intracellular calcium levels through the activation of voltage-sensitive calcium channels (20). To examine whether or not an increase in intracellular calcium levels has any effect on the steady state levels of Kvl.4 transcript, beating neonatal rat ventricular myocytes were stimulated with BAY-K 8644 in the presence of $5.4 \mathrm{mM} \mathrm{KCl}$ contained in culture medium. RT-PCR analyses demonstrate that the levels of Kv1.4 transcript in cardiomyocyte-enriched culture cells are increased by up to threefold by BAY-K 8644, while those in nonmuscle cell-enriched culture are unaffected (Fig. $3 A$ ). The effects can be detected as early as $1 \mathrm{~h}$ after the addition of BAY-K 8644, and the response peaks at 3 to $5 \mathrm{~h}$ after stimulation. This is followed by a gradual decrease, reaching control levels by $24 \mathrm{~h}$. Addition of the calcium channel antagonist nifedipine before BAY-K 8644 completely inhibited the stimulation (Fig. $3 \mathrm{~A}$ ). Over the time course of the experiment, control cells did not show any change in steady state levels of the transcript. RT-PCR products of $\beta$-actin were also consistently unchanged (Fig. $3 \mathrm{~A}$ ).

Since it is suggested that an increase in intracellular calcium concentration lowers the threshold of PKC activation (21), we examined the effect of phorbol esters that can pharmacologically alter PKC activity on Kv1.4 mRNA levels. As shown in Fig. $4 A$, the levels of Kv1.4 transcript in cardiomyocyteenriched culture cells are increased up to 3.5-fold by TPA, while those in nonmuscle cell-enriched culture were unaffected. The stimulatory effect can be detected $1 \mathrm{~h}$ after the addition of TPA, and the response peaks at 3 to $5 \mathrm{~h}$ after stimulation. The stimulatory effect of TPA was completely blocked by the addition of $\mathrm{H}-7$ (Fig. $4 \mathrm{~A}$ ). A phorbol ester that does not stimulate PKC, 4- $\alpha$-phorbol, did not elicit any changes in Kv1.4 mRNA levels (data not shown). As shown in Fig. $4 \mathrm{~A}$, over the time course of experiments, RT-PCR products of $\beta$ actin were consistently unchanged. The combination of TPA and BAY-K 8644 induced the additive accumulation (fivefold) of Kv1.4 transcript $5 \mathrm{~h}$ after stimulation, suggesting the possibility that calcium mobilization and PKC are closely involved in the accumulation of Kv1.4 mRNA. In both the case of BAY-K 8644 and of TPA additions, experiments have been repeated four times with separate RNA samples, and arbitrary values normalized by $\beta$-actin and deletion-mutated cRNA of Kv1.4 are shown in Fig. $4 A$. An increase in intracellular cAMP levels by dibutyryl cAMP ( $1 \mathrm{mM}$ ) did not influence the steady state levels of Kv1.4 transcript in the cardiomyocyte-enriched culture cells (Fig. $3 C$ ). In addition, the stimulation with BAY$K 8644$ or TPA did not induce any significant change in the Kv1.5 mRNA levels (Figs. $3 B$ and $4 B$ ).

Developmental changes of ventricular Kv1.5 and Kv1.4 mRNA levels. Our previous study (4) and Swanson et al. (15) have shown that Kv1.5 mRNA levels are developmentally regulated. As shown in Fig. 5, Kv1.5 mRNA levels in ventricles are
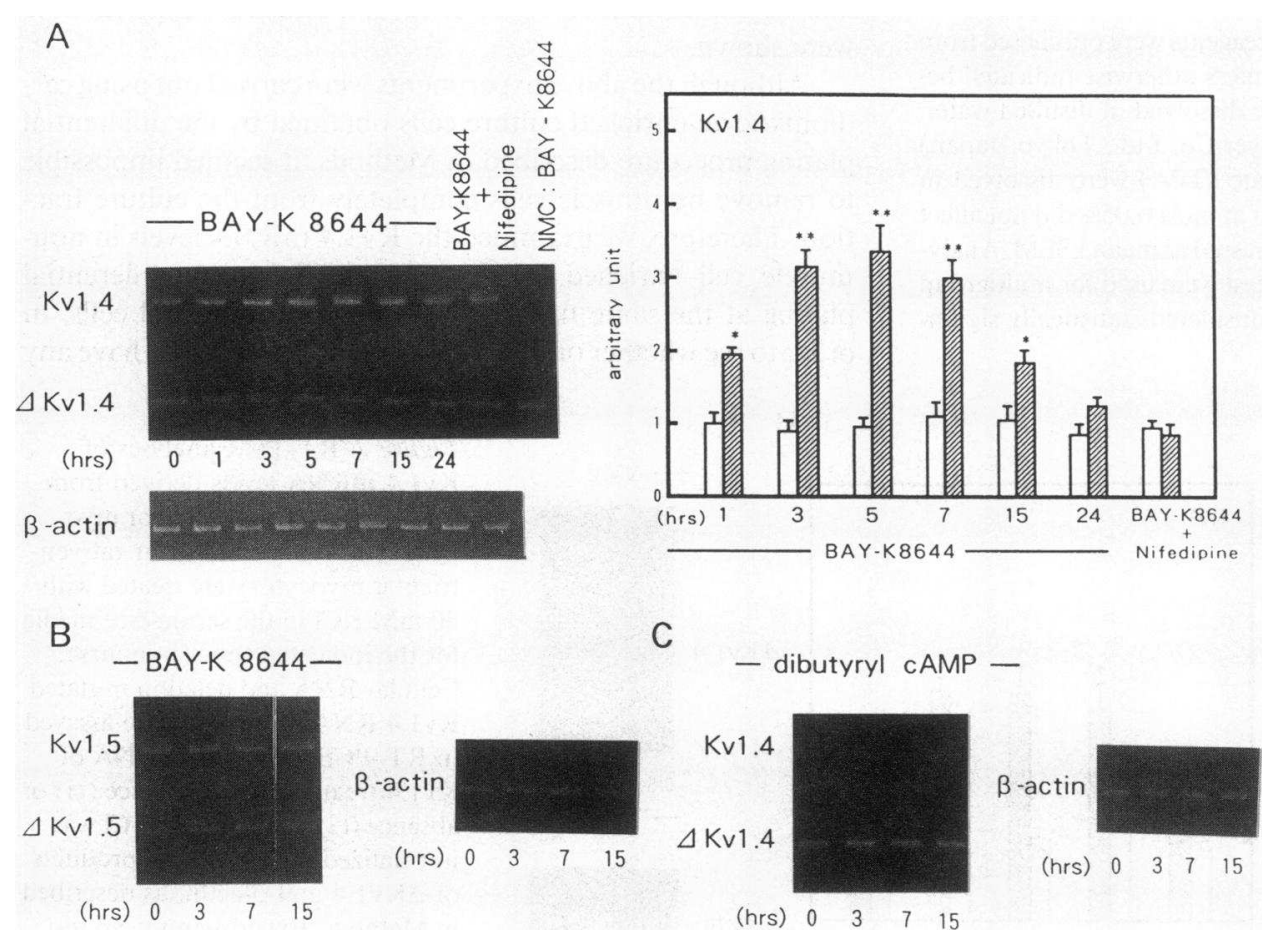

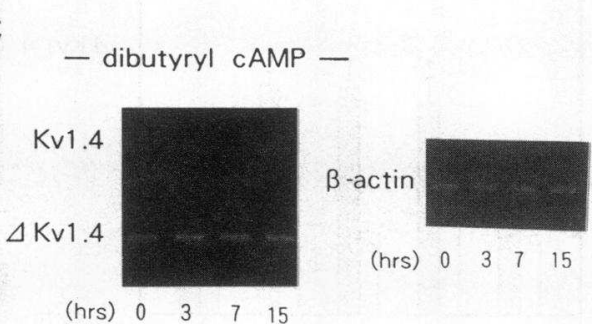

Figure 3. RT-PCR analyses of $\mathrm{Kv} 1.4$ and Kv1.5 mRNA levels derived from BAY-K 8644 treated cardiomyocytes. $(A)$ Neonatal Wistar rat ventricular myocytes were treated with BAY-K $8644(0.5 \mu \mathrm{M})$ in the presence of $5.4 \mathrm{mM} \mathrm{KCl}$ contained in serum-free media for the indicated time (in hours). In the experiment of BAY-K $8644(0.5 \mu \mathrm{M})$ + Nifedipine $(5 \mu \mathrm{M})$, the cells were treated for $5 \mathrm{~h}$ after the previous addition ( $30 \mathrm{~min}$ ) of the blocker. In nonmuscle cell-enriched culture $(N M C), \mathrm{BAY}-\mathrm{K} 8644(0.5 \mu \mathrm{M})$ was incubated for $5 \mathrm{~h}$. Cellular RNA and deletion mutated Kv1.4 RNA ( $\triangle \mathrm{Kv1.4)}$ were assayed in RT-PCR. Amplified cDNA of Kv1.4 treated in the presence ( $\square$ ) or absence ( $\square$ ) of BAY-K 8644 was normalized with the PCR products of $\triangle \mathrm{Kvl} .4$ and $\beta$-actin, as described in Methods. Experiments were repeated four times and the mean \pm SEM values $(n=4)$ are shown. ${ }^{*} P<0.05,{ }^{* *} P$ $<0.01$ vs. values in the absence of BAY-K 8644. (B) Neonatal Wistar rat atrial myocytes prepared with differential plating in the same method as ventricular myocytes were treated with BAY-K $8644(0.5 \mu \mathrm{M})$ for the indicated time. Cellular RNA $(500 \mu \mathrm{g})$ and $\Delta \mathrm{Kv1.5}$ RNA ( $10 \mathrm{pg})$ were analyzed with Kv1.5 primers. Experiments were separately repeated three times with similar results, and representative data are shown. $(C)$ Neonatal Wistar rat ventricular myocytes were treated with dibutyryl cAMP ( $1 \mathrm{mM})$ for the indicated time. Cellular RNA $(500 \mu \mathrm{g})$ and $\Delta \mathrm{Kv1} .4 \mathrm{RNA}(10 \mathrm{pg})$ were analyzed with Kv1.4 primers. No induction in Kv1.4 mRNA levels was observed $(n=4)$. 
A

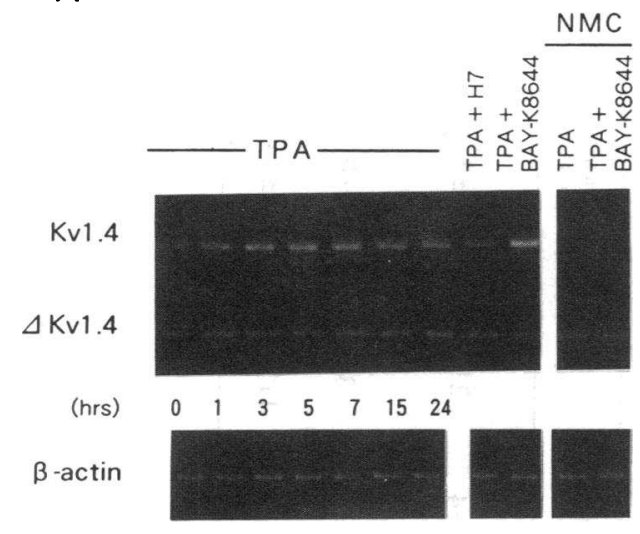

B

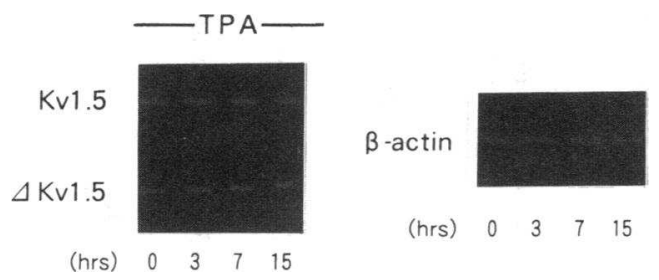

Figure 4. RT-PCR analyses of Kv1.4 and Kv1.5 mRNA levels derived from TPA-treated cardiomyocytes. $(A)$ Neonatal Wistar rat ventricular myocytes were treated with TPA $(1 \mu \mathrm{M})$, TPA $(1 \mu \mathrm{M})+\mathrm{BAY}$ $\mathrm{K} 8644(0.5 \mu \mathrm{M})$, or TPA $(1 \mu \mathrm{M})$ $+\mathrm{H}-7(5 \mu \mathrm{M})$ in the presence of 5.4 $\mathrm{mM} \mathrm{KCl}$ contained in serum-free media for the indicated time. In the experiment to examine the effect of blocker, the cells were treated for 5 $\mathrm{h}$ after the previous addition ( 30 $\mathrm{min}$ ) of the blocker. In nonmuscle cell-enriched culture $(N M C)$, TPA $(1 \mu \mathrm{M})$, or TPA $(1 \mu \mathrm{M})+\mathrm{BAY}-\mathrm{K}$ $8644(0.5 \mu \mathrm{M})$ was incubated for 5 h. Cellular RNA and deletion mutated Kv1.4 RNA ( $\triangle \mathrm{Kv1.4}$ ) were assayed with RT-PCR. Amplified cDNA of Kv1.4 treated in the presence ( $\square$ ) or absence ( $\square$ ) of TPA was normalized with $P C R$ products of $\Delta \mathrm{Kv} 1.4$ and $\beta$-actin as described in Methods. Experiments were separately repeated four times and the mean \pm SEM values $(n=4)$ are shown. ${ }^{*} P<0.05,{ }^{* *} P<0.01$ vs. values in the absence of TPA. $(B)$

Neonatal Wistar rat atrial myocytes prepared with differential plating in the same method as ventricular myocytes were treated with TPA ( $1 \mu \mathrm{M})$ for the indicated time. Cellular RNA ( $500 \mathrm{ng}$ ) and $\Delta \mathrm{Kv1} .5 \mathrm{RNA}(10 \mathrm{pg}$ ) were analyzed with Kv1.5 primers. Experiments were separately repeated three times with similar results and representative data are shown.

abundant at 4 wk, but less abundant in neonatal and elderly periods. These RT-PCR analyses are consistent with our previous data assayed by the RNase protection method (4). On the other hand, Kv1.4 mRNA levels showed developmental patterns quite different from those of Kv1.5 (Fig. 5). Kv1.4 transcripts are present most abundantly in neonatal and young adult periods and then decline with maturation, while RTPCR products of $\beta$-actin are similar over the time course of experiments. Thus, the developmental patterns of Kv1.5 and $\mathrm{Kv} 1.4$ gene expression in the heart are quite distinct, in spite of belonging to the same Shaker subfamily.

Differential changes of Kv1.5 and Kv1.4 mRNA levels in experimental cardiac hypertrophy. Cardiac hypertrophy is associated with changes in a wide range of intracellular signals, such as increased cytosolic free calcium, cAMP, inositol phosphates, and diacylglycerol concentrations (6). Because Kv1.5 and Kv1.4 mRNA levels in the heart could be modified by these signals, and because it is known that the plateau phase of the action potential is greatly altered in hypertrophic ventricles (7-9), we attempted to examine the expression patterns of these genes in response to cardiac hypertrophy in two distinct models of SHR and two-kidney, one-clip renovascular hypertensive rats (2K1C RHR). Table I shows the hemodynamic data of SHR and its genetic normotensive control, WKY.SHR are genetically hypertensive rat strains that have been studied widely and intensively in hypertension research (22). The ventricular hypertrophy suggested by a significant increase in the ratio of left ventricular and body weight, as compared to that in age-matched WKY, was observed at 20 wk, which was confirmed by the increased amounts of ANF mRNA, generally accepted as one of marks of ventricular hypertrophy (6). It is of interest to note that cardiac hypertrophy in SHR causes a dramatic reduction of Kv1.5 mRNA levels in ventricles (Fig. 6).
This reduction is evident as early as $17 \mathrm{wk}$ : Suggestive ventricular hypertrophy judged by the ratio of ventricular and body weight is not yet apparent, but the process of hypertrophic change has begun on a biochemical level, as indicated by the increased ANF mRNA levels. The reduction of ventricular Kv1.5 mRNA in WKY at 24 wk is consistent with the normal developmental pattern described in Fig. 5. On the other hand, Kv1.4 mRNA accumulations were remarkably increased in SHR at 20 and $24 \mathrm{wk}$, although the Kv1.4 mRNA levels in WKY at these weeks were decreased according to a normal developmental pattern. RT-PCR products of $\beta$-actin appeared to be similar in these hypertensive rats (Fig. 6). This differential response of ventricular Kv1.5 and Kv1.4 transcripts was consistently observed in all experimental rats (see Table I for numbers of animals).

To confirm further the differential change of Kv1.5 and Kv1.4 mRNAs and examine the effect of regression of cardiac hypertrophy on these changes, we employed the 2K1C RHR with more prominent ventricular hypertrophy. The clipped renal artery produces increased levels of plasma renin, aldosterone, and angiotensin II, resulting in the severe renovascular hypertension-induced hypertrophy (14). The elevated level of blood pressure can be completely normalized by the removal of clipped kidney or treatment by angiotensin I converting enzyme (ACE) inhibitor, accompanied by the regression of cardiac hypertrophy. Table I shows the hemodynamic data and cardiac ANF mRNA levels in sham-operated controls and 2K1C RHR untreated for 6 or $10 \mathrm{wk}$ after clipping, or treated with nephrectomy and enalapril (ACE inhibitor) for 4 wk after the 6-wk clipping. The presence of cardiac hypertrophy is suggested by the remarkably increased values of the ratio of left ventricular and body weight (twofold) and left ventricular ANF mRNA levels (eightfold), when compared to those in the 


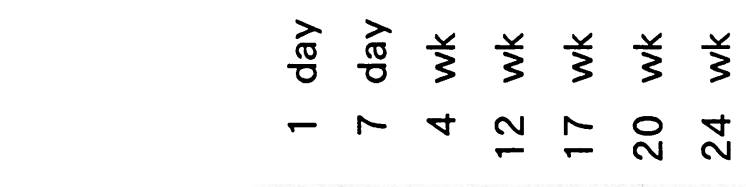

$\mathrm{K} v 1.5$

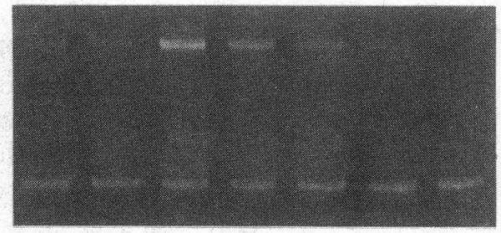

$\Delta \mathrm{Kv} 1.5$

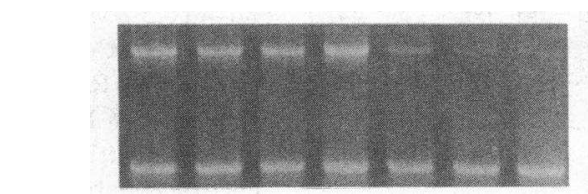

$\Delta \mathrm{Kv} 1.4$

Kv1.4

$\beta$-actin

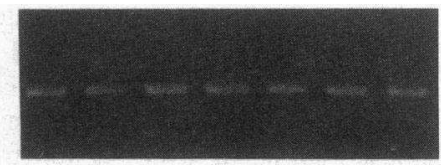

Figure 5. RT-PCR analyses of developmental changes in the accumulation of ventricular Kv1.4 and Kv1.5 mRNA levels. Tissue RNA obtained from Sprague-Dawley rat ventricles in different developmental stages was assayed with deletion mutated RNA by RT-PCR. Experiments were repeated with similar results in three separate samples, and representative results are shown.

sham-operated controls. Nephrectomy and treatment with enalapril for $4 \mathrm{wk}$ completely normalized the ratio of ventricular and body weight and ventricular ANF mRNA levels. Fig. 6 shows the expression patterns of Kv1.5 and Kv1.4 mRNAs in the development ( 6 and $10 \mathrm{wk}$ after clipping) and regression of cardiac hypertrophy. Similar to the results of SHR, Kv1.5 mRNA levels are dramatically repressed and Kv1.4 mRNA levels are remarkably augmented in the untreated 2 K1C RHR. The differential changes of these mRNAs appears to be more apparent than those in SHR. Treatments with enalapril and nephrectomy reversed these changes to the normal steady state levels, together with the regression of hypertrophy. Similar results were observed consistently in all experimental rats (see Table I for numbers of animals).

\section{Discussion}

Understanding the expression mechanisms for $\mathrm{K}^{+}$channel genes represents an informative initial step toward elucidating the function of specific $\mathrm{K}^{+}$channel proteins. The anatomical distribution and pathological changes of the various types of voltage-sensitive $\mathrm{K}^{+}$channels in the mammalian heart have been difficult to study, partly because of the paucity of high affinity ligands or pharmacological antagonists effective as specific probes in contrast to neurotransmitter-gated channels or sodium channels (23). However, the successful cloning of a family of $\mathrm{K}^{+}$channel cDNA has greatly facilitated the approach to this problem.

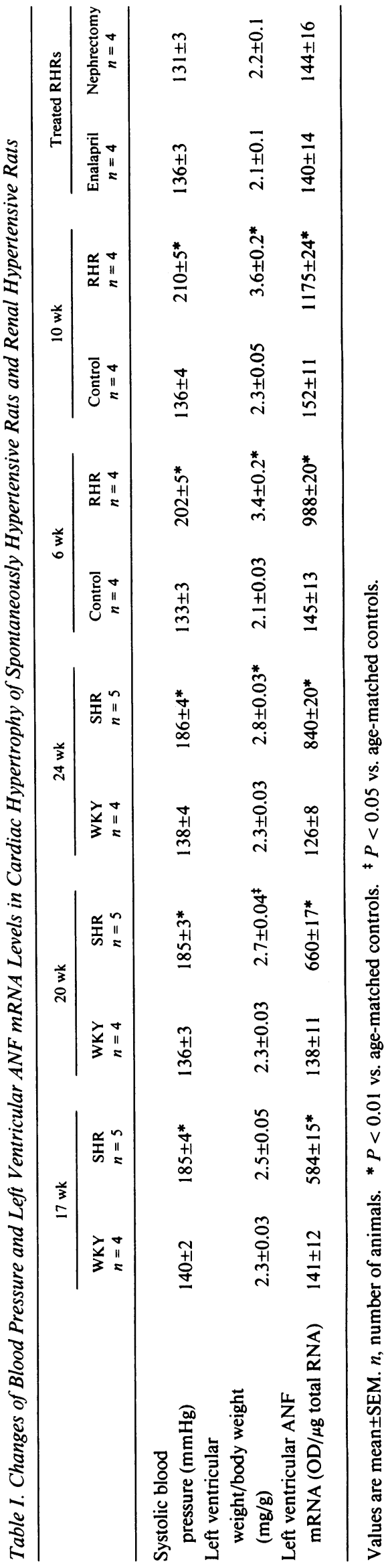




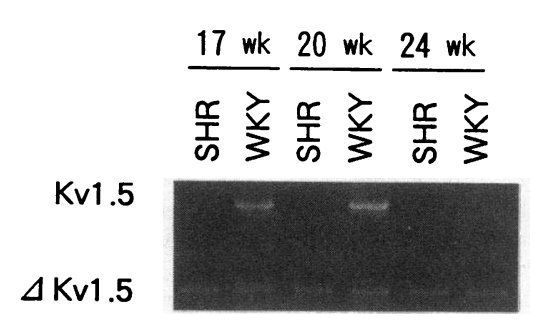

\begin{tabular}{c|c|}
$K v 1.4$ & $\square$ \\
$\Delta K v 1.4$ &
\end{tabular}

$\beta$-actin

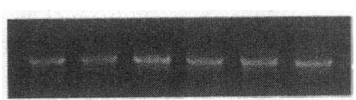

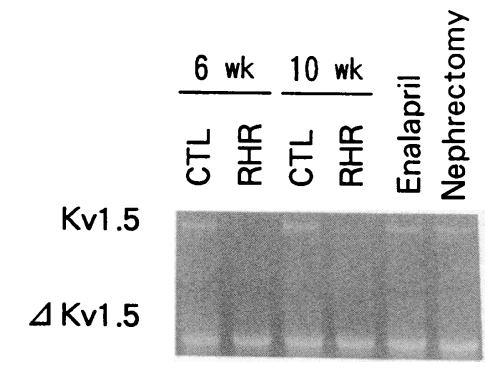

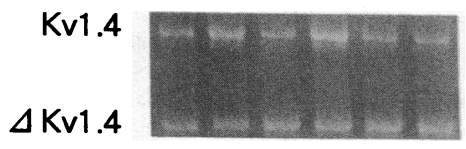

$\beta$-actin
Figure 6. RT-PCR analyses of differential accumulations of $\mathrm{Kv} 1.4$ and $\mathrm{Kv} 1.5$ transcripts in the development and regression of ventricular hypertrophy. Total RNA ( $1 \mu \mathrm{g})$, obtained from SHR or $2 \mathrm{~K} 1 \mathrm{C}$ RHR ventricles in different developmental stages of hypertrophy, were assayed with $10 \mathrm{pg}$ of deletion-mutated RNA by RT-PCR. 2KIC RHR were produced in male Kbl: Wistar rats (4-wk-old) by placing a silver clip $(0.2 \mathrm{~mm})$ on the left renal artery. The regression of ventricular hypertrophy was performed by antihypertensive treatments with enalapril or nephrectomy of the clipped kidney after the lateral renal artery had been clipped for 6 wk. Experiments were repeated with similar results in separate samples (see Table I for numbers of experimental rats), and representative results are shown.
In the first part of our experiments, we raised the possibility that the Kv1.4 mRNA levels are regulated with a rise in intracellular calcium and activation of PKC. Since we have reported that the Kv1.5 gene transcript is upregulated by intracellular cAMP levels (5), this suggests that Kv1.4 and Kv1.5 expressions are regulated through different intracellular pathways, despite belonging to the same Shaker subfamily. Transient elevation of intracellular calcium levels affects the threshold of PKC activation (21), which may act directly or indirectly to cause mRNA accumulation of Kv1.4 gene; PKC may phosphorylate other proteins that induce the maturation of Kv1.4 mRNA or directly regulate its gene transcription. Thus, the regulation of Kv1.4 and Kv1.5 expression by intracellular signals, and therefore by the multiple hormones that modulate the activities of CAMP, intracellular calcium, and PKC, could play an important role in the modulation of cardiocyte or neuron excitability. In the present study, we demonstrated that changes in membrane potential by the addition of high concentration $\mathrm{KCl}$ resulted in an early change in the steady state mRNA level of $\mathrm{Kv} 1.4$, as also observed in Kv1.5 mRNA regulation (19), suggesting the presence of new feedback mechanisms that depolarization itself affects the $\mathrm{K}^{+}$channel gene regulation important for repolarization.

The heart is composed of a number of different cells, such as myocytes, fibroblasts, endothelial cells, vascular smooth muscle cells, and others, among which myocytes and fibroblasts are predominant cell types in the case of the neonatal rat heart (24). Our RT-PCR analysis shows that Kv1.4 and Kv1.5 genes are expressed only in myocytes, not in fibroblasts, which is similar to the observation that $\mathrm{Kv} 1.1, \mathrm{Kv} 1.2$, and $\mathrm{Kv} 4.2$ channel genes are predominantly expressed in many different types of neurons rather than in glial cells (25). These imply that $\mathrm{Kv}$ channel genes are regulated in cell-type specific expression in the heart and brain. Compared with immediate early genes like protooncogene, whose mRNAs peak within $1 \mathrm{~h}$ after stimulation and fall back to baseline within a few hours (26), the change in Kv1.4 and Kv1.5 mRNAs is also transient, but the time course is slightly slower, suggesting that they may belong to the late response group of genes $(25,27)$. It has been assumed that late-responding genes may be regulated at the transcriptional level by the products of immediate early genes, many of which encode DNA-binding proteins $(27,28)$. Although it is unknown whether Kv1.4 expression is regulated in this fashion, further investigation at the molecular level would be needed to determine its transcriptional regulation.

Although it is not known whether or not the increase in transcript abundance may result in an actual increase in channel protein in vivo, previous work indicated that when Kv1.1 was expressed in Sol 8 cells under the control of the metallothionein promoter, an increase in the steady state level of mRNA resulted in the expression of a higher number of functional channels as measured by $\mathrm{K}^{+}$current density (29). The physiological correlates of these changes in channel abundance are being currently explored. A further source of increased complexity in vivo is the potential for different $\mathrm{K}^{+}$channel subunits to form heteromultimers that have properties distinct from those of the parent homomultimers (30-32). Tsaur et al. demonstrate that $\mathrm{Kvl} .1$ and $\mathrm{Kv1} .2$ may multimerize in neurons in many regions of the brain, as has been found in the Xenopus oocyte expression system (25). If so, even slight alterations in the relative level of expression of either Kv1.4 or $\mathrm{Kv} 1.5$ gene might have significant effects on the composition of Kv1.4-Kv1.5 heteromultimers, and thus may account for a variety of $\mathrm{K}^{+}$conductance recorded in the cardiomyocytes. Whether formation of $\mathrm{K}^{+}$channel heteromultimers actually occurs in vivo is unknown, therefore a further biochemical approach, such as producing the appropriate antibody specific for individual $\mathrm{K}^{+}$channel protein, is required at the protein level to address this issue.

Myocardial hypertrophy in both human and animal models such as SHR and 2K1C RHR is associated with changes in intracellular signals, including increased cAMP, intracellular calcium, inositol phosphates, and diacylglycerol concentrations closely involved in PKC activation (for review see reference 6). The second part of our experiments demonstrates that Kv1.4 mRNA accumulation is stimulated, while Kv1.5 mRNA is repressed in response to cardiac hypertrophy. This differential expression was repeated with similar results in the different types of ventricular hypertrophy of SHR and 2K1C RHR, and was normalized by the regression of hypertrophy, indicating that these interesting phenomena are a specific and consistent feature of hypertrophied myocardium. 
Electrophysiological studies have demonstrated that the transmembrane action potentials recorded from hypertrophied ventricles of rat $(8,9)$, cat $(7)$, and human $(33)$ are greatly altered, typical changes being depression of the membrane voltage during the action potential plateau and prolongation of the plateau phase. Such alterations in the action potential were also recorded in hypertrophied ventricles of $2 \mathrm{~K} 1 \mathrm{C}$ RHR (7-14 wk after clipping) produced from Wistar rats (8) or in those of 16-wk-old SHR (9), the same experimental models as in the present study. The delayed rectifier $\mathrm{K}^{+}$current is one of important outward $\mathrm{K}^{+}$currents involved in the configuration of cardiac action potential (1). TenEick et al. have demonstrated that the prolonged duration is closely involved in a significant decrease in the time-dependent outward current (34). Our observation that delayed rectifier $\mathrm{Kv} 1.5$ expression is remarkably repressed could account for one of the important molecular mechanisms responsible for the prolonged duration of action potential recorded in hypertrophied ventricles. Compared to the role of delayed rectifier Kv1.5 in hypertrophy, the effect of increased expression of rapidly inactivating Kv1.4 on the altered action potential remains to be determined. Such alterations in the repolarization time may be in part involved in the frequent occurrence of ventricular dysrhythmia in patients with hypertrophic hearts $(33,35)$. Thus, since the voltage-sensitive Shaker $\mathrm{K}^{+}$channel expressions could be changed from the steady state level in response to many signal transductions, it is likely that $\mathrm{K}^{+}$conductance and action potential are readily altered in many pathological stages such as hypertrophy, ischemia, and heart failure. Our present study is the first to demonstrate such phenomena in the molecular level, and further investigation of $\mathrm{K}^{+}$channel gene regulation in human diseased heart is now in progress.

\section{Acknowledgments}

This study was supported in part by Research Grants from the Ministry of Education, Science and Culture, Japan and the CIBA-GEIGY Foundation (Japan) for the Promotion of Science, and the Mochida Memorial Foundation for Medical and Pharmaceutical Research, and the Study Group of Molecular Cardiology in Japan.

\section{References}

1. Binah, O., I. Cohen, and N. Datyner. 1990. Repolarizing currents. In Cardiac Electrophysiology. M. R. Rosen, M. J. Janse, and A. L. Wit, editors. Futura Publishing Co., Mount Kisco, NY. 91-115.

2. Roberds, S. L., and M. M. Tamkun. 1991. Cloning and tissue-specific expression of five voltage-gated potassium channel cDNAs expressed in rat heart. Proc. Natl. Acad. Sci. USA. 88:1798-1802.

3. Stühmer, W., J. P. Ruppersberg, K. H. Schröter, B. Sakmann, H. Stocker, K. P. Giese, A. Perschke, A. Baumann, and O. Pongs. 1989. Molecular basis of functional diversity of voltage gated potassium channels in mammalian brain. EMBO (Eur. Mol. Biol. Organ.) J. 8:3235-3244.

4. Matsubara, H., E. R. Liman, P. Hess, and G. Koren. 1991. Pretranslational mechanisms determine the type of potassium channels expressed in the rat skeletal and cardiac muscles. J. Biol. Chem. 266:13324-13328.

5. Mori, Y., H. Matsubara, and G. Koren. 1992. cAMP modulates the expression of a rat delayed rectifier $\mathrm{K}^{+}$channel at the pretranslational level. J. Mol. Cell Cardiol. 24:S277. (Abstr.)

6. Morgan, H. E., and K. M. Baker. 1991. Cardiac hypertrophy, mechanical, neural, and endocrine dependence. Circulation. 83:13-25.

7. TenEick, R. E., A. L. Bassett, and L. L. Robertson. 1983. Possible electrophysiological basis for decreased contractility associated with myocardial hypertrophy in the cat: a voltage clamp approach. In Perspectives in Cardiovascular Research. Vol. 7. N. R. Alpert, editor, Raven Press, New York. 245-259.
8. Aronson, R. S. 1980. Characteristics of action potentials of hypertrophied myocardium from rats with renal hypertension. Circ. Res. 47:443-454.

9. Hayashi, H., and S. Shibata. 1974. Electrical property of cardiac cell membrane of spontaneously hypertensive rat. Eur. J. Pharmacol. 27:355-359.

10. Matsubara, H., Y. Hirata, H. Yoshimi, S. Takata, Y. Takagi, Y. Umeda, Y. Yamane, and M. Inada. 1988. Role of calcium and protein kinase C in ANP secretion by cultured rat cardiocytes. Am. J. Physiol. 255:H405-H409.

11. Dostal, D. E., K. N. Rothblum, K. M. Conrad, G. R. Cooper, and K. M. Baker. 1992. Detection of angiotensin I and II in cultured rat cardiac myocytes and fibroblasts. Am. J. Physiol. 263:C851-C863.

12. Rogers, T. B., S. T. Gaa, and I. S. Allen. 1986. Identification and characterization of functional angiotensin II receptors on cultured heart myocytes. J. Biol. Chem. 236:438-444.

13. Dösemeci A., R. S. Dhallan, N. M. Cohen, W. J. Lederer, and T. B. Rogers. 1988. Phorbol ester increases calcium current and stimulates the effects of angiotensin II on cultured neonatal rat heart myocytes. Circ. Res. 62:347-357.

14. Matsubara, H., J. Yamamoto, Y. Hirata, Y. Mori, S. Oikawa, and M. Inada. 1990. Changes of atrial natriuretic peptide and its messenger NRA with development and regression of cardiac hypertrophy in renovascular hypertensive rats. Circ. Res. 66:176-184.

15. Swanson, R., J. Marshall, J. S. Smith, J. B. Williams, M. D. Boyle, K. Folander, C. J. Luneau, J. Antanvage, C. Oliva, S. A. Buhrow, et al. 1990. Cloning and expression of cDNA and genomic clones encoding three delayed rectifier potassium channels in rat brain. Neuron. 4:929-939.

16. Tokunaga K., H. Taniguchi, K. Yoda, M. Shimizu, and S. Sakiyama. 1986. Nucleotide sequence of a full-length cDNA for mouse cytoskeletal $\beta$-actin mRNA. Nucleic Acids Res. 14:2829-2830.

17. Gilman, M. 1991. Ribonuclease protection assay. In Current Protocol in Molecular Biology. F. M. Ausubel, R. Brent, R. E. Kingston, D. D. Moore, J. G. Seidman, J. A. Smith, and K. Struhl, editors. Greene Publishing Associates, Brooklyn, NY. 4.7.1-4.7.3.

18. Wang, A. M., M. V. Doyle, and D. Mark. 1989. Quantitation of mRNA by the polymerase chain reaction. Proc. Natl. Acad. Sci. USA. 86:9717-9721.

19. Mori, Y., A. Siegel, and G. Koren. 1992. cAMP modulates the expression of a rat delayed rectifier $\mathrm{K}^{+}$channel at the transcriptional level. Circulation. 86:I-26. (Abstr.)

20. Rasmussen, H., and P. Q. Barrett. 1984. Calcium messenger system: an integrated view. Physiol. Rev. 64:938-984.

21. Nishizuka, Y. 1984. The role of protein kinase $C$ in cell surface signal transduction and tumor promotion. Nature (Lond.). 308:693-698.

22. Yamori, Y., and W. Lovenberg. 1987. Spontaneously hypertensive rats. Hypertension, 9(Suppl. I):I-13-I-14.

23. Jan, L. Y., and Y. N. Jan. 1989. Voltage-sensitive ion channels. Cell. 56:13-25.

24. Pinson, A., P. Padieu, and I. Harary. 1987. Techniques for culturing heart cells. In The Heart Cell in Culture. Vol. 1. A. Pinson, editor. CRC Press, Boca Raton, FL. 7-22.

25. Tsaur, M. L., M. Sheung, D. H. Lowenstein, Y. H. Jan, and L. Y. Jan. 1992. Differential expression of $\mathrm{K}^{+}$channel mRNAs in the rat brain and downregulation in the hippocampus following seizures. Neuron. 8:1055-1067.

26. Sadoshima, J., L. Jahn, T. Takahashi, T. Kulik, and S. Izumo. 1992. Molecular characterization of the stretch-induced adaptation of cultured cardiac cells, an in vitro model of load-induced cardiac hypertrophy. J. Biol. Chem. 267:10551-10560.

27. Sheng, M., and M. E. Greenberg. 1990. The regulation and function of c- fos and other immediate early genes in the nervous system. Neuron. 4:477-485.

28. Curran, T., and J. I. Morgan. 1987. Memories of fos. Bioessays. 7:255258.

29. Koren, G., E. R. Liman, D. E. Logothetis, B. Nadal-Ginard, and P. Hess. 1990. Gating mechanism of a cloned potassium channel expressed in frog oocytes and mammalian cells. Neuron. 4:39-51.

30. Christie, M. J., J. P. Adelman, J. Douglas, and R. A. North. 1989. Expression of a cloned rat brain potassium channel in Xenopus oocytes. Science (Wash. DC). 244:221-224.

31. Isacoff, E. Y., Y. N. Jan, and L. Y. Jan. 1990. Evidence for the formation of heteromultimeric potassium channels in Xenopus oocytes. Nature (Lond.). 345:530-534.

32. Ruppersberg, J. P., K. H. Schroter, B. Sakmann, M. Stocker, S. Sewing, and O. Pongs. 1990. Heteromultimeric channels formed by rat brain potassium channel proteins. Nature (Lond.). 345:535-537.

33. TenEick, R. E., and D. E. Singer. 1979. Electrophysiological properties of diseased human atrium. I. Low diastolic potential and altered cellular response to potassium. Circ. Res. 44:545-557.

34. TenEick, R., H. Gelband, M. Goode, and A. Bassett. 1978. Increased inward rectifying potassium current in cat ventricle subjected to chronic pressure overload. Circulation. 58(Suppl. II):II-47. (Abstr.)

35. TenEick, R. E., C. M. Baumgarten, and D. H. Singer. 1982. Ventricular dysrhythmia: membrane basis, or, of currents, channels, gates and cables. Prog. Cardiovasc. Dis. 24:157-162. 